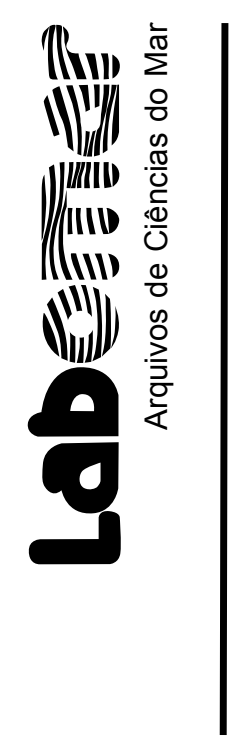

NOTA CIENTÍFICA

\title{
LENGTH-WEIGHT RELATIONSHIP OF MARINE COMMERCIAL FISH SPECIES IN RIO DE JANEIRO STATE, BRAZIL
}

\section{Relação peso/comprimento de alguns peixes comerciais marinhos do Estado do Rio de Janeiro, Brasil}

\author{
Magda Fernandes de Andrade-Tubino', Melquíades Pinto Paiva²
}

\begin{abstract}
Length-weight relationship parameters of thirteen species of demersal and pelagic fishes that are of economic and ecological relevance in the commercial fisheries of Rio de Janeiro State, southeastern of Brazil, are presented. These relationships indicate a positive allometry tendency for the regression slope, $\boldsymbol{b}$ in the sampled fish community.
\end{abstract}

Key words: length-weight relationship, demersal and pelagic fishes, Rio de Janeiro State.

\section{RESUMO}

Foram estimados os parâmetros da relação peso-comprimento de 13 espécies de peixes demersais e pelágicos que apresentam importância econômica e ecológica nas pescarias comerciais do Estado do Rio de Janeiro, Sudeste de Brasil. Estas relações indicam uma tendência de alometria positiva para o coeficiente angular da regressão, $\boldsymbol{b}$ na comunidade amostrada.

Palavras-chaves: relação peso-comprimento, peixes demersais e pelágico, Estado do Rio de Janeiro.

\footnotetext{
${ }^{1}$ Laboratório de Biologia e Tecnologia Pesqueira, Universidade Federal do Rio de Janeiro, Prédio do CCS, Av. Prof. Rodolfo P. Rocco, 211, Rio de Janeiro, RJ 21949-900.

2 Doutor em Ciências pela Universidade de São Paulo, Professor Titular (aposentado) da Universidade Federal do Ceará, Diretor Emérito do Instituto de Ciências do Mar, e Sócio Honorário do Instituto Histórico e Geográfico Brasileiro. Endereço para correspondência: Rua Baronesa de Poconé, 71/701, Rio de Janeiro, RJ 22471-270. E-mail: < mappaiva@uol.com.br >
} 


\section{INTRODUCTION}

The relationship between length and weight of the fish's body presents great importance in fisheries biology studies (Sparre et al., 1989), being used broadly with different purposes, namely to estimate the mean weight of fish based on a known length value (Beyer, 1987), to convert growth equations in length into the equivalent one in weight, to compare interspecific and intrapopulation morphometry, and to determine the index of well-being of individual fish (Bolger \& Connoly, 1989).

The length-weight relationship is usually calculated through a log-transformed linear regression (Zar, 1996), whose parameter b estimated from the potential equation $\left(W=a \cdot L^{b}\right)$ is also known as allometric coefficient, which measures the relative gains in weight for a given fish length. Great variations in estimates of $\mathbf{b}$ are observed among different populations of the same species or within one same population at different times. This difference can reflect changes in the individuals' condition in relation to feeding, reproduction and migratory activities (King, 1995).

The objective of this paper is to determine the length-weight relationship of thirteen species of demersal and pelagic fishes that are of economic

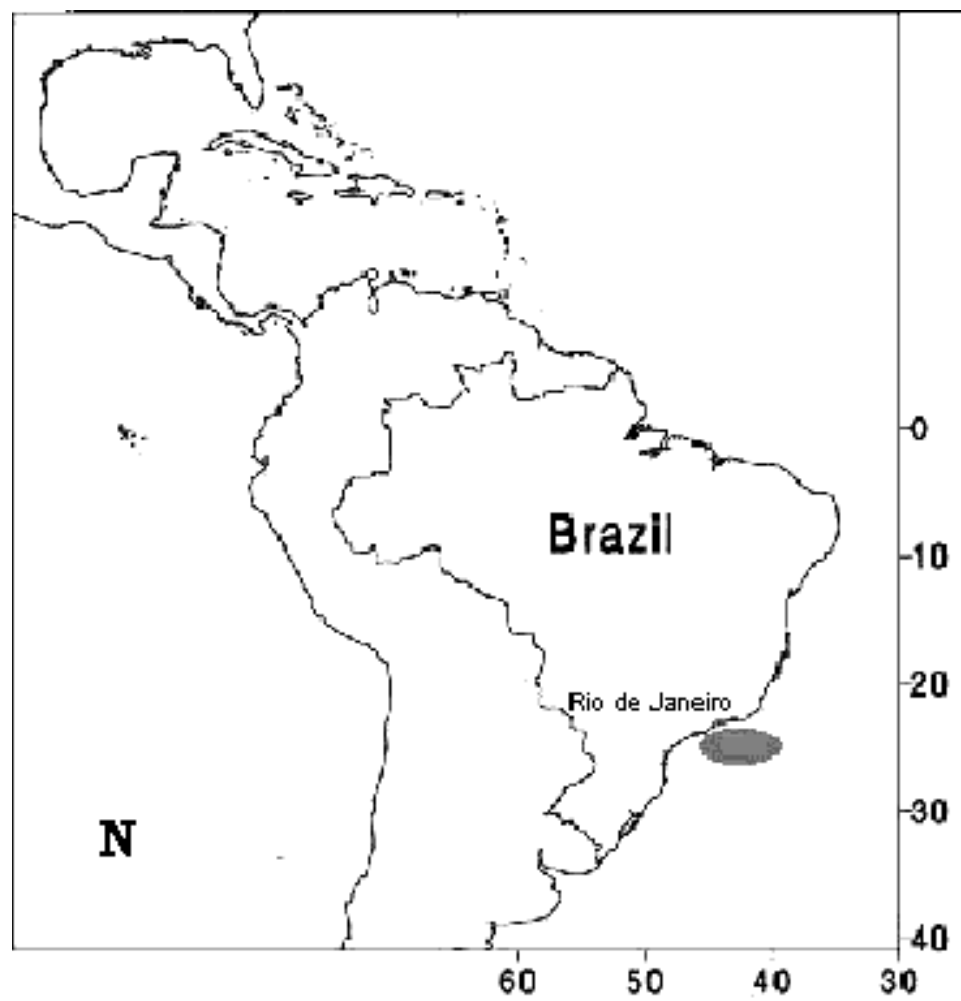

Figure 1 - Map showing the main fishing grounds (shaded area) exploited by the commercial fleet off the southeastern Brazilian coast. and ecological relevance in the commercial marine fisheries of Rio de Janeiro State, southeastern Brazil.

\section{MATERIAL AND METHODS}

The database for this study was obtained from specimens sampled from landings made in the São Pedro fish market (Niterói, Rio de Janeiro State). They were caught with long-lines and midwater trawl nets by fishing boats operating in the Cabo Frio area $\left(23^{\circ} / 24^{\circ} \mathrm{S}-041^{\circ} 30^{\prime \prime} / 042^{\circ} 30^{\prime \prime} \mathrm{W}\right)$. The samples for Brazilian sardine, Sardinella brasiliensis, were acquired from purse seine-captured shoals at Angra dos Reis $\left(23^{\circ}-24^{\circ} \mathrm{S}-44^{\circ}-045^{\circ} \mathrm{W}\right)$.

In the period from June, 1999 to May, 2000 a number of fish were sampled and measured for the following morphometric variables: total length, with a $0.1 \mathrm{~cm}$ accuracy, and total weight, with a $1.0 \mathrm{~g}$ accuracy of a electronic scale. Sex-separated sampling was made only for two species, namely Brazilian sardine and sandperch.

The parameters $\mathbf{a}$ and $\mathbf{b}$ of the weight (W)/ length $(\mathrm{L})$ regression of the thirteen species were estimated using the log-transformed equation: $\ln W$ $=\ln \mathrm{A}+\mathrm{b} \ln \mathrm{L}$.

Correlation between weight and length was ascertained through the determination coefficient $\left(R^{2}\right)$, and sex differences in the length-weight relationship of Brazilian sardine and sandperch were submitted to statistical analysis by the $\boldsymbol{t}$ test for two slopes (b), after the methodology described by Ivo \& Fonteles-Filho (1997).

\section{RESULTS AND DISCUSSION}

The fitting of length-weight relationships by regression referred to thirteen species distributed among nine families, as follows: Serranidae, with three species, Sciaenidae, with two species, and the others with one species each. In all, they are represented by 4,330 sampled specimens, out of which 2,227 account for Sardinella brasiliensis. Three species are pelagic, namely Brazilian sardine, common snook and fat snook, and the other ten, demersal. Sex was identified for all sampled individuals of sandperch, but not for 61 specimens of Sardinella brasilensis, what is not expected to cause any major effect on the significance of the regression equations for males and females. Except for the small-sized Brazilian sardine, all species are medium-sized ones (Table I and Glossary, for common names). 
Table I - Data on sample numbers $(\mathrm{N})$, and minimum, maximum and mean values for total length and total weight of marine commercial fishes by sex, family and species, off Rio de Janeiro State, Brazil.

\begin{tabular}{|c|c|c|c|c|c|c|c|c|c|}
\hline \multirow{2}{*}{ Family $^{(1)}$} & \multirow{2}{*}{ Species ${ }^{(2)}$} & \multirow{2}{*}{ Sex } & \multirow{2}{*}{$\mathrm{N}$} & \multicolumn{3}{|c|}{ Total length $(\mathrm{cm})$} & \multicolumn{3}{|c|}{ Total weight (kg) } \\
\hline & & & & $\min$. & $\max$. & mean $(\bar{x})$ & $\min$. & $\max$. & mean $(\bar{x})$ \\
\hline \multirow[t]{3}{*}{ Clupeidae } & \multirow[t]{3}{*}{ Sardinella brasiliensis } & Male & 1,148 & 14.8 & 26.0 & $18.6 \pm 1.6$ & 0.03 & 0.1 & $0.06 \pm 0.01$ \\
\hline & & Female & 1,068 & 13.7 & 28.0 & $19.5 \pm 1.6$ & 0.02 & 0.1 & $0.07 \pm 0.01$ \\
\hline & & Both $^{(3)}$ & 2,277 & 13.7 & 28.0 & $18.9 \pm 1.7$ & 0.02 & 0.1 & $0.06 \pm 0.01$ \\
\hline \multirow[t]{2}{*}{ Centropomidae } & Centropomus undecimalis & Both & 112 & 29.0 & 76.7 & $52.9 \pm 12.1$ & 0.2 & 5.2 & $1.6 \pm 1.2$ \\
\hline & Centropomus parallelus & Both & 148 & 23.7 & 78.9 & $45.0 \pm 9.4$ & 0.1 & 5.6 & $1.1 \pm 0.9$ \\
\hline \multirow[t]{3}{*}{ Serranidae } & Epinephelus marginatus & Both & 127 & 25.1 & 90.9 & $47.6 \pm 12.6$ & 0.3 & 17.3 & $2.6 \pm 2.6$ \\
\hline & Epinephelus niveatus & Both & 229 & 23.4 & 122.3 & $46.1 \pm 9.3$ & 0.1 & 12.7 & $4.4 \pm 2.1$ \\
\hline & Mycteroperca rubra & Both & 147 & 25.0 & 74.3 & $41.3 \pm 12.2$ & 0.2 & 4.8 & $1.1 \pm 1.0$ \\
\hline Priacanthidae & Priacanthus arenatus & Both & 127 & 29.9 & 53.5 & $40.3 \pm 4.9$ & 0.5 & 2.6 & $1.1 \pm 0.4$ \\
\hline Malacanthidae & Lopholatilus villarii & Both & 228 & 24.2 & 92.6 & $38.4 \pm 4.7$ & 0.2 & 16.4 & $4.3 \pm 1.3$ \\
\hline Pomatomidae & Pomatomus saltatrix & Both & 148 & 36.9 & 91.6 & $57.3 \pm 10.8$ & 0.5 & 6.1 & $1.7 \pm 1.0$ \\
\hline Sparidae & Pagrus pagrus & Both & 149 & 24.4 & 64.4 & $38.5 \pm 7.8$ & 0.2 & 3.9 & $1.0 \pm 0.6$ \\
\hline \multirow[t]{2}{*}{ Sciaenidae } & Cynoscion acoupa & Both & 113 & 47.3 & 118.0 & $71.3 \pm 16.3$ & 1.0 & 15.7 & $3.9 \pm 3.0$ \\
\hline & Micropogonias furnieri & Both & 151 & 24.3 & 71.3 & $47.9 \pm 8.1$ & 0.2 & 4.5 & $1.3 \pm 0.8$ \\
\hline \multirow[t]{3}{*}{ Pinguipedidae } & Pseudopercis numida & Male & 246 & 39.1 & 114.0 & $66.2 \pm 12.9$ & 0.7 & 17.2 & $3.8 \pm 2.6$ \\
\hline & & Female & 128 & 23.8 & 80.5 & $55.6 \pm 10.8$ & 0.2 & 6.7 & $2.3 \pm 1.2$ \\
\hline & & Both & 374 & 23.8 & 114.0 & $62.6 \pm 13.2$ & 0.2 & 17.2 & $3.3 \pm 2.4$ \\
\hline
\end{tabular}

Remarks: 1 = families' sequence according to Nelson (1994); 2 = scientific names according to Froese \& Pauly (2003); $3=$ number higher than the sum of males and females because sex identification was not amenable for all individuals.

The high statistical significance of the determination coefficient $\left(\mathrm{R}^{2}\right)$, which varied in the range of $0.85-0.99(\mathrm{P}<0.01)$, attested to the existence of strong correlation between length and weight. Statistical significance in the length-weight relationship between sexes was observed for Sardinella brasiliensis $(\mathrm{t}=18.63 ; \mathrm{P}<0.01)$ and Pseudopercis numida (6.28; $\mathrm{P}<0.01$ ), so that sex-specific regression equations are presented. For the other species, only one regression equation is available, since their data were analyzed for both sexes together (Table II).

Table II - Data on regression equation, curve interception (A) and determination coefficient $\left(R^{2}\right)$ of the length-weight relationship for demersal and pelagic fishes, in the marine fisheries of Rio de Janeiro State, Brazil

\begin{tabular}{|c|c|c|c|c|}
\hline \multirow{2}{*}{ Common name } & \multirow{2}{*}{ Sex } & \multirow{2}{*}{ Equations } & \multicolumn{2}{|c|}{ Parameters } \\
\hline & & & $\mathrm{A}$ & $\mathrm{R}^{2}$ \\
\hline \multirow[t]{3}{*}{ Brazilian sardinella } & Male & $\ln W=\ln -2.94+2.400 \ln L$ & 0.052744 & 0.86 \\
\hline & Female & $\ln W=\ln -3.69+2.655 \ln L$ & 0.025052 & 0.85 \\
\hline & Both & $\ln W=\ln -3.46+2.578 \ln L$ & 0.031350 & 0.86 \\
\hline Common snook & Both & $\ln W=\ln -12.66+3.267 \ln L$ & 0.000003 & 0.98 \\
\hline Fat snook & Both & $\ln W=\ln -11.79+3.092 \ln L$ & 0.000008 & 0.96 \\
\hline Dusky grouper & Both & $\ln W=\ln -11.71+3.210 \ln L$ & 0.000008 & 0.99 \\
\hline Snowy grouper & Both & $\ln W=\ln -10.70+2.904 \ln L$ & 0.000011 & 0.96 \\
\hline Mottled grouper & Both & $\ln W=\ln -10.98+2.921 \ln L$ & 0.000017 & 0.99 \\
\hline Atlantic big-eye & Both & $\ln W=\ln -10.33+2.814 \ln L$ & 0.000033 & 0.97 \\
\hline Tilefish & Both & $\ln W=\ln -11.95+3.184 \ln L$ & 0.000009 & 0.98 \\
\hline Bluefish & Both & $\ln W=\ln -10.09+2.601 \ln L$ & 0.000042 & 0.96 \\
\hline Common seabream & Both & $\ln W=\ln -10.52+2.852 \ln L$ & 0.000027 & 0.95 \\
\hline Acoupa weakfish & Both & $\ln W=\ln -11.54+2.987 \ln L$ & 0.000010 & 0.98 \\
\hline Croaker & Both & $\ln W=\ln -11.56+3.030 \ln L$ & 0.000010 & 0.95 \\
\hline \multirow[t]{3}{*}{ Sandperch } & Male & $\ln W=\ln -11.63+3.063 \ln L$ & 0.000009 & 0.97 \\
\hline & Female & $\ln W=\ln -11.33+2.999 \ln L$ & 0.000012 & 0.98 \\
\hline & Both & $\ln W=\ln -11.36+2.634 \ln L$ & 0.000012 & 0.88 \\
\hline
\end{tabular}


The values of $\mathbf{b}$ varied from 2.400 , for males of Sardinella brasiliensis, to 3.267 for Centropomus undecimalis, with an average $2.837 \pm 0.288$ at $95 \%$ confidence the level. The estimated figures are in agreement with Pauly \& Gayanilo Jr. (1997), in the sense that $\mathbf{b}$ should vary in the range of $2.5-3.5$, what allows for the occurrence of isometry, and negative and positive allometry in the length-weigh relationship.

A tendency for a negative allometry in relative growth of the thirteen analyzed species suggests a restriction to the use of the isometric condition factor, a parameter related to individual size and sexual maturity, because of an inverse variation occurring between the regression's slope (b) and its intercept (a). Similar observations were made by Braga (1993 and 1997) in analyses of the weight-length allometric equation and the condition factor in, respectively, Paralonchurus brasiliensis and Plagioscion squamosissimus.

\section{REFERENCES}

Beyer, J.E. On length-weight relationships. Part I: Computing the mean weight of the fish of a given length class. Fishbyte, n.5, p.11-13, 1987.

Bolger, T. \& Connolly, P.L. Selection of suitable indices for the measurement and analysis of fish condition. J. Fish Biol., v.34, p.171-182, 1989.

Braga, F.M.S. Análise do fator de condição de $P a-$ ralonchurus brasiliensis (Perciformes, Sciaenidae). Revista UNIMAR, v.15, n.2, p.99-115, 1993.

Braga, F.M.S. Análise da equação alométrica na relação peso e comprimento e o fator de condição em Plagioscion squamosissimus (Teleostei-Sciaenidae). Rev. Brasil. Biol., v.57, n.3, p.417-425, 1997.

Ivo, C.T.C. \& Fonteles-Filho, A.A. Estatística Pes- queira. Aplicação em Engenharia de Pesca. TOM Gráfica e Editora, v+193 p., Fortaleza, 1997.

Froese, R. \& Pauly, D. FishBase. Version 3.0 (06 Abril 2004). World Electronic Database. Disponível em http://www.fishbase.org, acessado em 01/02/2007, 2003.

King, M. Fisheries biology, assessment and management. Fishing News Books, 341 p., Oxford, 1995.

Nelson, J.S. Fishes of the world. John Wiley \& Sons, Inc., $3^{\text {rd }}$ edition., $x x+600$ p., New York, 1994.

Pauly, D. \& Gayanillo Jr., F. C. Abee: an alternative approach to estimating the parameters of a lengthweight relationship from length-frequency samples and their bulk weights. NAGA, Manila, v.22,n.1, p.15-26, 1997.

Sparre, P.; Ursin, C. \& Venema, S.C. Introduction to tropical fish stock assessment. Part I - Manual. FAO Fish. Tech. Pap., n.306, p.1-376 p., 1989.

Zar, J.H. Biostatistical analysis. Prentice-Hall Inc., $3^{\text {rd }}$ edition, 662 p., Englewood Cliffs, 1996.

Glossary of common names. Mottled grouper = Mycteroperca rubra (Bloch, 1793); tilefish = Lopholatilus villari Miranda-Ribeiro, 1915; snowy grouper = Epinephelus niveatus (Valenciennes, 1828); croaker = Micropogonias furnieri (Desmarest, 1823); bluefish = Pomatomus saltatrix (Desmarest, 1823); dusky grouper = Epinephelus marginatus (Lowe, 1834); sandperch = Pseudopercis numida Miranda-Ribeiro, 1903; Atlantic big-eye $=$ Priacanthus arenatus Cuvier, 1829; common seabream = Pagrus pagrus (Linnaeus, 1758); acoupa weakfish = Cynoscion acoupa (Lacépede, 1802); common snook $=$ Centropomus undecimalis (Bloch, 1792); fat snook = Centropomus parallelus Poey, 1860; Brazilian sardinella $=$ Sardinella brasiliensis (Steindachner, 1879). 